J. Lake Sci. (湖泊科学), 2020, 32(5): 1333-1347

DOI 10. 18307/2020. 0500

(c) 2020 by Journal of Lake Sciences

\title{
1960s 以来白洋淀水文、环境、生态演变趋势”
}

\author{
易雨君 ${ }^{1,2 * *}$, 林楚尧 $^{1}$, 唐彩红 ${ }^{1}$ \\ (1: 北京师范大学环境学院水沙科学教育部重点实验室, 北京 100875) \\ (2: 北京师范大学环境学院水环境模拟国家重点实验室, 北京 100875)
}

\begin{abstract}
摘 要: 白洋淀是我国华北平原最大的浅水湖泊湿地, 享有 “华北之肾”、“华北明珠”等美誉,对维持京津冀大城市群的 区域生态系统平衡和保持生物多样性发挥着生态安全屏障作用. 长期以来, 高强度人类活动导致人淀水量锐减、水体污 染严重、生物多样性减少、生态系统功能衰退, “明珠” 失去了应有的光泽. 结合历史文献资料和课题组长期在白洋淀的监 测结果, 本文系统地梳理了自 1960s 以来,白洋淀的水文、水环境和水生态演变历程, 并分析了导致一系列演变发生的可 能原因. 随着区域经济的发展, 人类活动增强, 白洋淀区域水量、水环境以及生态质量自 $1960 \mathrm{~s}$ 以来逐渐退化. 近 20 年来, 随着一系列环境治理政策和生态补水工程的实施, 白洋淀水质恶化趋势得到了一定的遏制. 2017 年, 中共中央、国务院宣 布设立雄安新区, 其 “以水定城” 的理念突显白洋淀作为新区中心的重要性, 白洋淀环境与生态治理工作任重而道远. 本 文的工作以期能为新时期白洋淀的环境生态治理提供依据和支持.
\end{abstract}

关键词: 白洋淀;生态补水;雄安新区;生态修复;浅水湖泊

\section{Hydrology, environment and ecological evolution of Lake Baiyangdian since 1960s*}

\author{
YI Yujun ${ }^{1,2 * *}$, LIN Chuqiao ${ }^{1} \&$ TANG Caihong ${ }^{1}$ \\ (1: State Key Laboratory of Water Environment Simulation, School of Environment, Beijing Normal University, Beijing \\ 100875 , P.R.China) \\ (2: Ministry of Education Key Laboratory of Water and Substrate Science, School of Environment, Beijing Normal University, \\ Beijing 100875, P.R.China)
}

\begin{abstract}
Lake Baiyangdian is the largest shallow lake in the North China Plain. It enjoys the reputation of "the Kidney of North China" and "the pearl of North China". It plays a role as an ecological security barrier to maintain the regional ecosystem balance and biodiversity of the Beijing-Tianjin-Hebei metropolitan area. For a long time, intensive human activities have led to a sharp decreasing in the amount of water into the Lake Baiyangdian, serious water pollution, and the decline of biodiversity and ecosystem functions. Therefore, the "Pearl" has lost its luster. Combined with historical documents and the long-term monitoring results on this lake, this paper systematically reviews the evolution of hydrology, water quality and water ecology in the Lake Baiyangdian since 1960s, and analyzes the possible reasons for the evolution. With the development of regional economy and the enhancement of human activities, the water quantity, water environment and ecological quality in the Lake Baiyangdian have been gradually degraded since the 1960s. In the past 20 years, with the implementation of a series of environmental control policies and ecological water replenishment projects, the deterioration trend of Lake Baiyangdian water quality has been curbed to some extent. In 2017, the CPC Central Committee and the State Council announced the establishment of the Xiong'an New Area. Its concept of "setting the city by water" highlights the importance of the Lake Baiyangdian as the center of the new area, which has a long way to go in environmental and ecological management. This paper is expected to provide a basis and support for the environmental and ecological management of the Lake Baiyangdian in the new period.
\end{abstract}

Keywords: Lake Baiyangdian; ecological water replenishment; Xiong'an New Area; ecological restoration; shallow lake

* 2020-03-19 收稿;2020-04-28 收修改稿.

国家自然科学基金创新研究群体项目(51721093)、国家重点研发计划项目(2017YFC0404500)和国家自然科学基 金优秀青年基金项目 (51722901) 联合资助.

** 通信作者;E-mail : yiyujun@ bnu.edu.cn. 
湿地是陆地生态系统和水生生态系统相互作用形成的独特生态系统, 是动植物重要的栖息环境, 也是 自然界最富生物多样性的生态系统. 其具有抵御洪水、调节径流、改善气候、控制污染、美化环境和维护区域 生态平衡等生态服务功能,被誉为“地球之肾”、“生命的摇篮”、“文明的发源地” 和 “物种的基因库” ${ }^{[1-3]}$. 近 年来, 由于全球气候变化和人类活动的加剧, 湿地面积大幅度持续缩减. 据世界经济合作与发展组织 (OECD) 的统计, 1900 年以来全球已有接近 $50 \%$ 的湿地消失 ${ }^{[4]}$, 越来越多的湿地正面临严重的危机. 我国也 针对此危机采取了包括立法、建立自然保护区等一系列湿地保护与管理的相关措施,截至 2015 年,共投人 保护资金 150 亿元, 减缓了 $49 \%$ 的湿地功能衰退 ${ }^{[5]}$.

白洋淀位于海河流域大清河水系的“九河下梢” (图 1a), 是我国华北平原为数极少且最大的淡水湖泊 湿地. 白洋淀曾经水域辽阔, 水质良好, 水产资源丰富, 享有 “华北之肾”、“华北明珠” 等美誉 ${ }^{[6]}$, 发挥着调节 气候、蓄水兴利、渔苇生产、旅游景观、保护生物多样性等多种重要生态功能. 近半个世纪以来, 由于气候变 化和人类活动的综合作用, 白洋淀湿地面临水源不足、湿地萎缩、水体污染、泥沙淤积、生物多样性减少等问 题, 水质污染影响了白洋淀流域的工农业生产和城市生活用水安全, 导致其生态系统服务功能衰退 ${ }^{[7-8]}$.

为了“把白洋淀修复好、保护好” ${ }^{[9]}$,国家和地方政府也采取了一系列生态环境保护措施. 2002 年,河北 省政府批准《白洋淀湿地自然保护区规划》, 设立了白洋淀湿地省级自然保护区; 2012 年, 《白洋淀省级自然 保护区总体规划 (修编版) 》对保护区进行了调整, 进一步扩大了保护区范围与面积; 2015 年, 河北省发展和 改革委员会编制了《白洋淀环境综合整治与生态修复规划 (2015-2020 年) 》, 指出实施引水补水调水、污染 源综合治理、村镇综合整治、人淀河流整治、淀区管护维护、区域产业转型和能力设施建设等 8 项重点任务; 2017 年, 白洋淀与洱海、丹江口一起被纳人环境保护部“新三湖” 水污染治理体系. 2017 年 4 月 1 日, 中共中 央、国务院设立河北雄安新区. 2018 年 4 月中共河北省委、河北省人民政府颁布的《河北雄安新区规划纲 要》正式划定了雄安新区的范围 (图 1b), 白洋淀作为雄安新区的后花园, 统筹城水林田淀系统治理, 做好白 洋淀生态环境保护, 恢复“华北之肾”功能, 是雄安新区打造新时代生态文明典范城市的重要环节. 2019 年 1 月颁布了《白洋淀生态环境治理和保护规划 (2018-2035 年)》, 规划从流域治理角度出发, 统筹考虑了水 量、水质、生态 3 大要素, 以白洋淀水质、水生态恢复目标为抓手, 通过补水、治污、清淤、搬迁等措施综合治 理,全面恢复白洋淀“华北之肾”功能,使“华北明珠”重放光彩 ${ }^{[10]}$.

目前, 针对白洋淀环境生态问题已经开展了大量的研究,包括水体富营养化监测与评价 ${ }^{[11]}$ 、重金属 ${ }^{[12]}$ 和新兴污染物 ${ }^{[13]}$ 的污染特征与风险分析、大型水生植物关键影响因子识别与生物量模拟 ${ }^{[14]}$ 、浮游植物和浮 游植物群落结构特征及其对营养状态的响应 ${ }^{[15]}$ 、基于广义可加模型的底栖动物分布模拟和预测 ${ }^{[16]}$ 、水利工 程建设对鱼类生存环境的影响 ${ }^{[17]}$ 以及沉积物中微生物群落结构对人类活动的响应 ${ }^{[18]}$ 等工作. 本文正是基 于前期大量的研究, 在查阅大量历史资料和实地调查、监测、研究的基础上, 系统梳理了 1950s 以来白洋淀人 淀水量、生态补水、水质条件和典型生物群落的组成和演变, 并分析了演变的可能原因, 以期为白洋淀的环 境生态修复与治理提供有益的支持.

\section{1 材料与方法}

\section{1 白洋淀概况}

白洋淀流域是海河流域大清河水系中游的缓洪滞洪区, 承担着洪水调蓄功能, 是我国水资源开发利用 程度最高、水资源最为紧缺的流域之一, 对维护华北平原的生态平衡起着不可替代的作用 ${ }^{[19]}$. 它承接着大 清河水系九条河流来水, 有 “九河下梢”之称, 现代地理中这 9 条河是指渚龙河、孝义河、唐河、清水河、瀑河、 府河、萍河、漕河、白沟引河 (图 1a).

不同于太湖、巢湖等其他大型浅水湖泊, 白洋淀地形独特, 河淀相连、沟壑纵横, 3700 多条沟壕和河道将 143 个大小不同的淀泊连接在一起, 形成芦苇田、园田台地、洼地、村庄相融合的独特自然景观 ${ }^{[20]}$. 在众多淀 泊中, 超过 600 万 $\mathrm{m}^{2}$ 淀泊共 7 个, 包括白洋淀、烧车淀、马棚淀、羊角淀、池鱼淀、后塘、小北淀, 60 万 600 万 $\mathrm{m}^{2}$ 的淀泊共 24 个, 60 万 $\mathrm{m}^{2}$ 以下的淀泊共 112 个, 在所有淀泊中白洋淀面积最大, 故得此名 ${ }^{[21]}$, 水域、台田、 耕地与农田是白洋淀的主要景观类型.

\section{2 研究方法}

本研究通过收集并整理文献、统计年鉴、保定市水文局和国家气象数据中心的历史数据, 与课题组采样 
数据相结合, 归纳总结了白洋淀水量、水质与水生态的演变历程. 具体参数包括:气温、降水量、人淀水量与 水位; 水体中总氮 $(\mathrm{TN})$ 、总磷 $(\mathrm{TP}) 、$ 、化学需氧量 $(\mathrm{COD})$ 、溶解氧 $(\mathrm{DO})$ 浓度和沉积物中重金属含量; 水生态系 统中维管束植物、浮游生物、底栖动物、鱼类和其他生物物种数等. 其中, 课题组共选择 12 个有代表性的区 域进行调查和采样,采样点按生境类型可分为干扰区和半自然区. 其中干扰区采样点包括: 端村 (D1)、圈头 (D2)、淀头 (D3)、鹗鸢岛 (D4)、东关码头 (D5) 和旅游码头 (D6) ; 半自然区包括采蒲台 (S1)、光淀张庄 (S2)、柊林庄 (S3)、王家寨 (S4)、大口子 (S5) 和烧车淀 (S6) (图 1c). 历史数据所引用的参考文献标注在图 题上, 其余数据来自课题组采样或保定市水文局、国家气象数据中心.
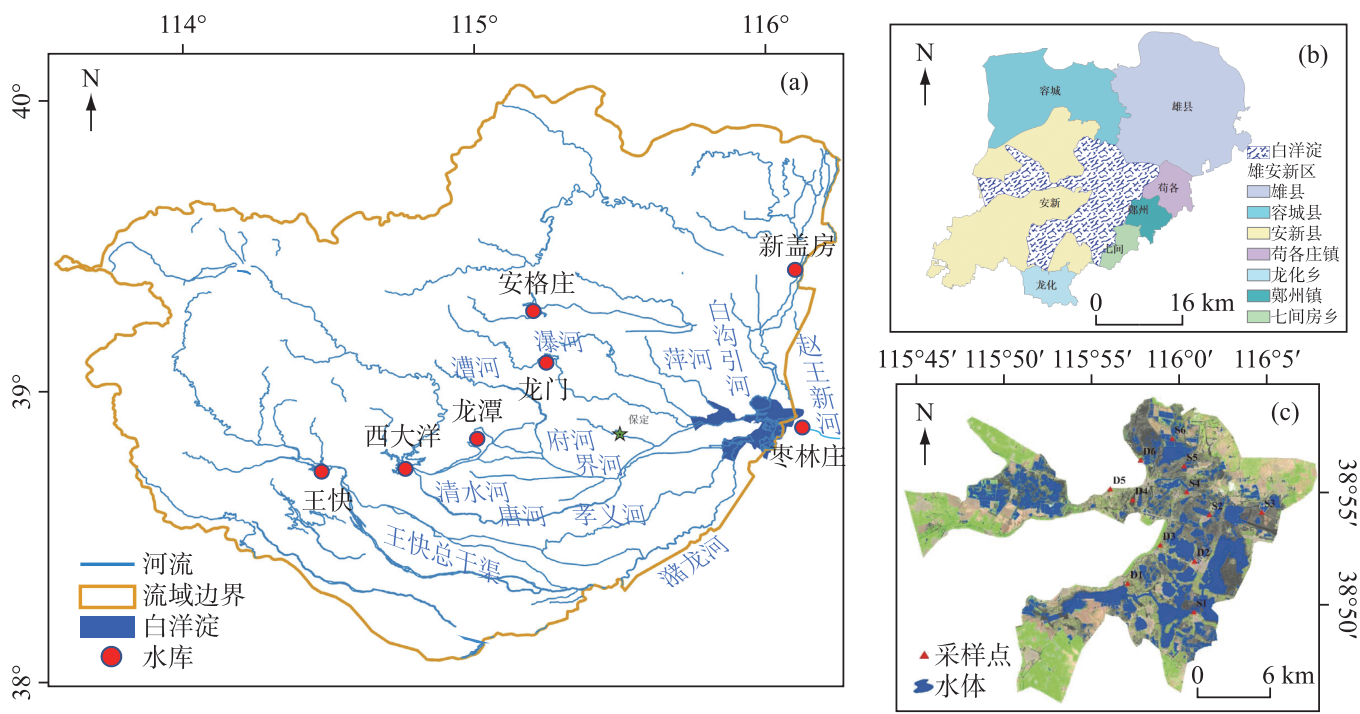

图 1 白洋淀流域示意图: (a) 白洋淀流域水系结构及主要水库分布;

(b) 白洋淀及雄安新区区域图; (c) 白洋淀淀区地形及采样点分布

Fig.1 Baiyangdian Basin schematic diagram: (a) Baiyangdian Basin water system structure and main reservoirs distribution; (b) Regional map of Lake Baiyangdian and Xiong'an New District;

(c) Distribution of topography and sampling sites in Lake Baiyangdian

\section{2 水文条件}

\section{1 水系格局}

1960s 以前, 白洋淀上游河流基本未受人类活动干扰, 径流通畅, 九河人淀, 而后经赵北口自溢东去, 但 也因泄水不畅经常发生洪涝灾害. 1963 年特大洪水灾害后,在“上蓄、中疏、下导、适当地滞”的防洪原则指 导下, 白洋淀上游河流水系开始修建一系列水利工程, 包括百万立方米以上的大、中、小型水库 53 座, 60 万 $\mathrm{m}^{2}$ 以上灌区 36 处, 大、中型扬水站 44 个, 灌溉面积约为 30 亿 $\mathrm{m}^{2}$. 新盖房水利枢纽工程的兴建和白沟引河的 开挖, 使原来不人淀的大清河北支也经由此人淀; 唐河新道的建成, 切断了金线河与清水河的人淀通道; 府 河清污分流, 清水人淀, 污水排人唐河污水库; 属于平原河流的孝义河、萍河常年干枯断流; 至此白洋淀实际 人淀河流仅剩 6 条. 下游出口则由苯林庄闸和赵北口溢流堰控制, 自赵王新河人大清河. 水利工程的修建有 利于防洪除涝和灌溉, 但也改变了白洋淀流域的水系格局, 白洋淀由天然过水型湖泊转变为人工调蓄型湖 泊. 目前, 人淀河流有大清河北支南拒马河和白沟河来水经白沟引河、新盖房闸人淀, 大清河南支 8 条人淀 河流除府河、孝义河外,其他河流仅在汛期有少量径流人淀.

\section{2 气候状态}

受气候变化影响, 自 1950s 以来, 白洋淀淀区年平均降水量呈现较大波动趋势, 总体呈逐步减少趋势. Walter 和 Breckle 于 1985 年提出了气候状态图, 通过温度和降水的季节变化、干旱和湿润季节的长度和强度等 


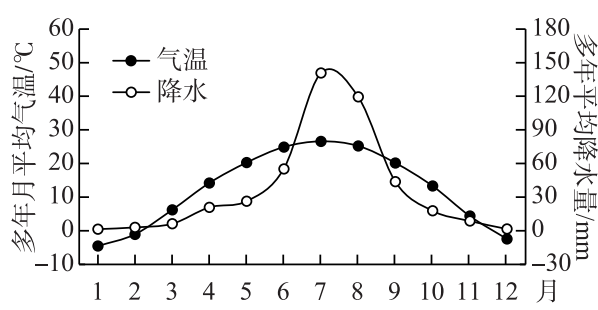

图 2 白洋淀 1960-2019 年期间气候状态

Fig. 2 Climate state of Lake Baiyangdian during 1960-2019

大量气候信息表征陆地植被分布和气候的关系 ${ }^{[22]}$. 王兆印 根据我国的气候特点, 给定了适合我国气候特征的月降水量 与气温的对应关系 ${ }^{[23]}$. 白洋淀多年平均气温为 $12.3^{\circ} \mathrm{C}$,多年 平均降水量为 $445 \mathrm{~mm}$. 基于安新水文站 1960-2019 年的月 降水和气温数据绘制的气候状态图 (图 2) 可知,白洋淀属于 典型的温带半干旱大陆性季风气候, 四季分明且雨热同期. 旱季(3-6月、9-11月)降水量低, 温度线位于降水量线上 方,气候干冷, 不利于植被发育, 降水是该区生态系统演化的 限制因子;雨季降雨丰富,且主要集中在 7、8 月,多以暴雨的 形式出现,降水量线在气温线上方,气候湿热, 此期间温度为 白洋淀生态系统演化的限制因子.

空间分布上,白洋淀流域降水的特点是地域分布比较均匀,降水量空间分布从西北山区向东南平原区 略减 ${ }^{[24]}$. 白洋淀降水量年际变化大, 大多数年份降水量小于多年平均降水量, 大于平均降水量的年份降水 量约为多年平均降水量的 2 倍, 常以局部暴雨的形式,易形成洪涝灾害.

\section{3 入淀水量与补水}

白洋淀人淀水量来自天然径流、上游水库补水和跨流域调水 3 部分. 人淀水量的变化随着自然和人类 活动的影响大致可以划分为以下 3 个阶段 (图 3): 第 I 阶段为 1965 年前, 未修建水利工程, 人淀水量丰富, 1956 年达到 51 亿 $\mathrm{m}^{3}$,与降水量基本同步,淀区水位在 $8 \mathrm{~m}$ 左右波动, 菄林庄枢纽对水位进行有效调控; 第 II 阶段为 1965-1997 年, 此时大量水利工程竣工并投人使用. 入淀水量明显减少, 1978 年减少到 11 亿 $\mathrm{m}^{3}$, 淀 区水位急剧降低, 干淀现象时常发生. 1983-1987 年白洋淀更是经历了长达 5 年的干淀期,生态环境急剧破 坏. 从 1981 年开始, 上游水库开始对白洋淀进行间歇性补水; 第 III 阶段为 1997 年至今, 人口增加、经济发展 导致用水量增加, 人淀水量急剧减少, 多年平均人淀水量仅为 2.4 亿 $\mathrm{m}^{3}$, 自然径流急剧减少, 上游水库开始 对白洋淀的补水力度加大, “引岳济淀” “引黄人冀” 以及南水北调等生态补水工程陆续实施, 白洋淀水位 开始恢复,在 $7 \mathrm{~m}$ 左右波动, 2015 年后水位持续升高. 这些措施避免了白洋淀水位降低甚至发生干淀的风 险, 在一定程度上遏制了白洋淀生态环境的破坏. 但人工补水改变了年内人淀流量过程, 洪峰流量由 7-8 月变为生态补水下的 $2-4$ 月,干扰了部分生物的生命节律.

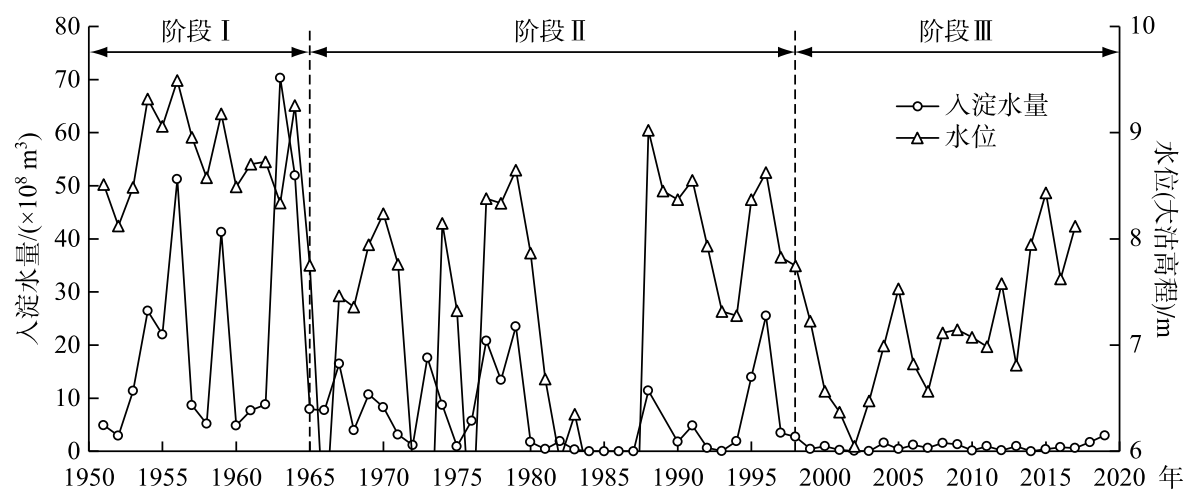

图 3 白洋淀人淀水量及水位演变过程 (水位为 1985 年国家高程基准) ${ }^{[25-26]}$

Fig. 3 Evolution process of water quantity and water level in Lake Baiyangdian (the water level is the national elevation standard in 1985) ${ }^{[25-26]}$

为了缓解人淀流量减少导致的淀区水位下降甚至干淀状况的发生, 1981-2019 年从上游水库 (王快水 库、西大洋水库、安各庄水库、岳城水库) 、“引黄济淀”、“引黄人冀” 补淀、南水北调等工程向白洋淀人工补 水 46 次, 累计输水总量为 $192.6 \times 10^{8} \mathrm{~m}^{3}$ (图 4). 2004 年完成“引岳济淀” 补水工程, 从海河岳城水库累计引 
水 $1.6 \times 10^{8} \mathrm{~m}^{3} ; 2006-2011$ 年先后实施了 5 次 “引黄济淀” 工程,共计引水入淀 $5.1 \times 10^{8} \mathrm{~m}^{3} ; 2016$ 年开工建 设 “引黄人冀” 补淀工程, 自兴阳黄河渠村闸引水,规划每年向白洋淀生态补水 $2.55 \times 10^{8} \mathrm{~m}^{3} ; 2018$ 年南水北 调工程实施后, 通过易县的瀑河、北易水两个退水闸向白洋淀补水, 年补水量约为 1 亿 $\mathrm{m}^{3}$. 这些措施在一定 程度上提高了白洋淀的水位, 避免了干淀状况发生, 对遏制白洋淀生态退化起到了良好作用, 未来更加稳定 和常态化的生态补水措施将持续为雄安新区的建设和发展保驾护航.

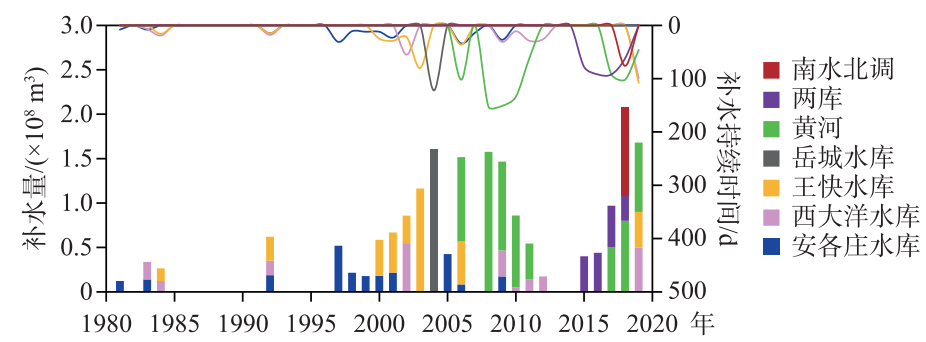

图 4 白洋淀历史补水水源/补水时间及补水量分布 ${ }^{[27-28]}$ (柱状图表示补水量,曲线对应补水持续时间)

Fig.4 Historical replenishment water source/replenishment time and replenishment water distribution in Lake Baiyangdian ${ }^{[27-28]}$

\section{3 水环境问题}

在 Web of Science 使用主题词“Baiyangdian”进行检索, 采用 CiteSpace 软件绘制了不同时间的主要关键 词. 图 5 反映了不同时期白洋淀的研究重点, 研究的重视程度在一定程度上反映了当时的环境生态问题. 关 于白洋淀的研究从 1995 年开始出现在国际期刊上, 关注的重点是水质, 尤其是氮、磷的问题; 21 世纪初, 随 着人淀水量的减少, 人淀河流与湖泊的关系研究开始成为关注的焦点; 2008 年开始, 关于白洋淀的污染问 题, 特别是富营养化和新兴污染物的问题成为热点; 2012 年开始, 沉积物的污染、新兴污染物如多环芳烃等 受到重视,白洋淀生态修复开始提上日程.

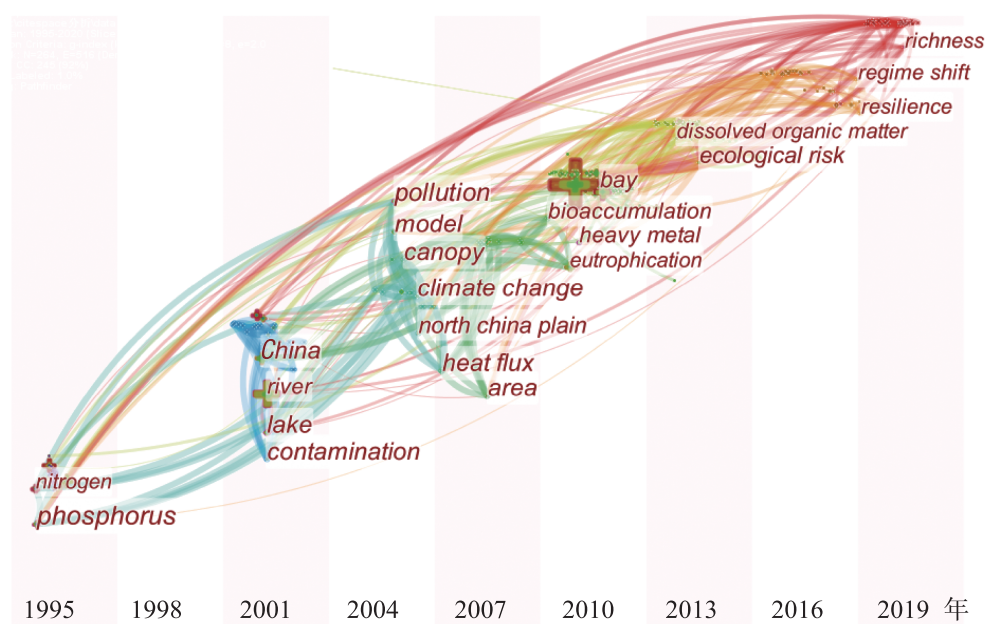

图 5 白洋淀 CiteSpace 关键词时区图

Fig.5 Time zone of Lake Baiyangdian with CiteSpace keywords

研究的发展趋势在一定程度上反映了不同时期白洋淀的关键环境问题. 针对以上几个主要关键词, 进 一步分类进行检索 (附表 I ). 随着人类活动的增强, 白洋淀整体的水质条件逐渐恶化, 尤其在 2005 年以后, 常年处于 $\mathrm{V}$ 类或劣 $\mathrm{V}$ 类 ${ }^{[29-30]}$. 水质的恶化引起了广泛的关注, 关于白洋淀水质问题的研究也在这一时期逐 
渐增多. 2010-2014 年, 随着“十一五水专项” 的实施, 每年相关的论文数量基本在 20 篇以上(附图 I a). 然 而, 水质条件并没有随着研究的增多而改善, 其原因可能是在一种污染得到有效治理的同时, 新的污染问题 又开始出现; 或是环境的治理不只是科学研究一方面的事情, 从认识污染、到治理方法、再到落实治理措施, 是一个研究和管理共同作用的过程.

白洋淀富营养化状态和相关研究的论文数量分布呈现很好的同步关系 (附图 I b). 该方面研究从 2005 年开始逐步增加, 在 2012、2013 年达到峰值, 在此期间, 白洋淀的富营养化状况为中度富营养. 自 2015 年, 白 洋淀富营养化程度由中度向轻度转变, 相应的研究热度也有所降低, 特别是 2017 年雄安新区设立以来, 水 体富营养化问题得到了较好的控制. 相比富营养化的研究, 重金属和新兴污染物的研究则少得多, 但可以看 出, 两者的研究一直较为平稳 (附图 I c, d). 由于新兴污染物具有稳定性、高毒性等特点, 将是未来白洋淀区 域治理研究需要持续关注的问题.

\section{1 水体质量}

白洋淀水体污染的来源广、途径多、种类复杂. 污染的主要来源有: 由府河排人淀内的保定市生活污水, 及其他上游河流汛期径流汇人的污染物、农业污染源、城镇污染源、旅游业污染源等. 1973 年以来, 白洋淀水 质总体上呈恶化趋势,水质条件受人淀水量影响大 (图 6) ${ }^{[29,31]}$. 1973-1983 年期间,除 1975 年由于突发性 水污染事件水质为 $\mathrm{V}$ 类水外, 其他年份水质均优于或等于 III 类水; 1985、1986 年为极干旱年, 干淀的同时水 质为 IV 类;1987-1996 年,随着自然径流的恢复和间歇性补水,水质依然维持在优于或等于 III 类水; 进人 21 世纪后, 白洋淀人淀流量急剧下降, 水体恶化加剧, 水质等级多处于 IV 类、V 类, 甚至在 2005、2006、2014 和 2015 年为劣 $\mathrm{V}$ 类.

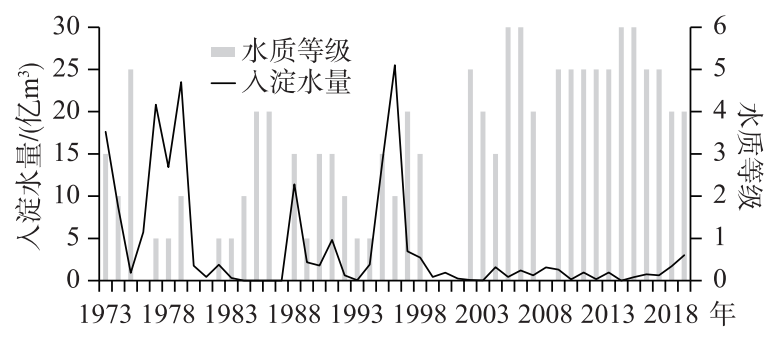

图 6 白洋淀逐年水质等级与人淀水量 (水质等级 1 6 分别表示 $\mathrm{I} \sim$ 劣 $\mathrm{V}$ 类水体) ${ }^{[29,31]}$

Fig. 6 Annual water quality grade and the amount of water into Lake Baiyangdian (the water quality grade 1 to 6 represent $I$-worse $V$ water body, respectively) ${ }^{[29,31]}$

作者分别统计了近年来白洋淀水体中 TN 、 TP、COD 和 DO 的逐年平均浓度变化趋势 (图 7), 根据我国 《地表水环境质量标准》(GB 3838- 2002) 中的湖、库水质标准, TP 和 TN 自 1997 年以来一直维持在较高浓 度水平, 尤其是 $\mathrm{TP}$ 浓度大部分年份超过了 V 类水标准. 2019 年, 通过一系列治理措施, $\mathrm{TP}$ 和 TN 浓度均有 大幅度下降, 基本能满足 III 类水标准. COD 浓度自 1970s 以来,一直呈逐渐升高态势, 2005 年以前属于 III 类 及以下;2006-2018 年平均浓度为 $31.58 \mathrm{mg} / \mathrm{L}$, 水质多属于 III V 类之间. 从淀区 COD 平均浓度来看, 2006 年开始水质明显恶化. 白洋淀 DO 浓度较高,多处于III类水及以上,对水质不构成威胁.

氮磷组成比率 ( TN/TP) 是衡量水体中氮或磷元素为藻类生长限制因子的关键指标. Guildford 和 Hecky $^{[33]}$ 在 Redfield 比值的基础上, 重新定义了淡水湖泊 TN/TP 的取值范围: TN/TP 质量比小于 9 时藻类 生长缺少氮元素, 为氮限制; TN/TP 质量比大于 23 时为磷限制; TN/TP 质量比为 $9 \sim 23$ 时, 藻类生长受 $\mathrm{N}$ 和 $\mathrm{P}$ 共同限制 ${ }^{[33-34]}$. 从近 23 年来白洋淀 TN/TP 计算结果可以看出 (图 8), TN/TP 比值波动较大, 最大值为 32 ( 2003 年), 最小值为 0.72 (1996 年), 仅有 3 个年份 TN/TP 略低于 9 , 表明白洋淀藻类生长整体为 P 限制和 $\mathrm{N} 、 \mathrm{P}$ 共同限制. 从 2007 年白洋淀水污染防治被列人国家 “水专项” 项目, 开展实施 “白洋淀水质改善与沼泽 化控制技术及工程示范研究” 以来, TN/TP 几乎维持在 $23: 1$ 以上, 因此可以认为目前白洋淀藻类的生长限制 性营养元素为磷. 

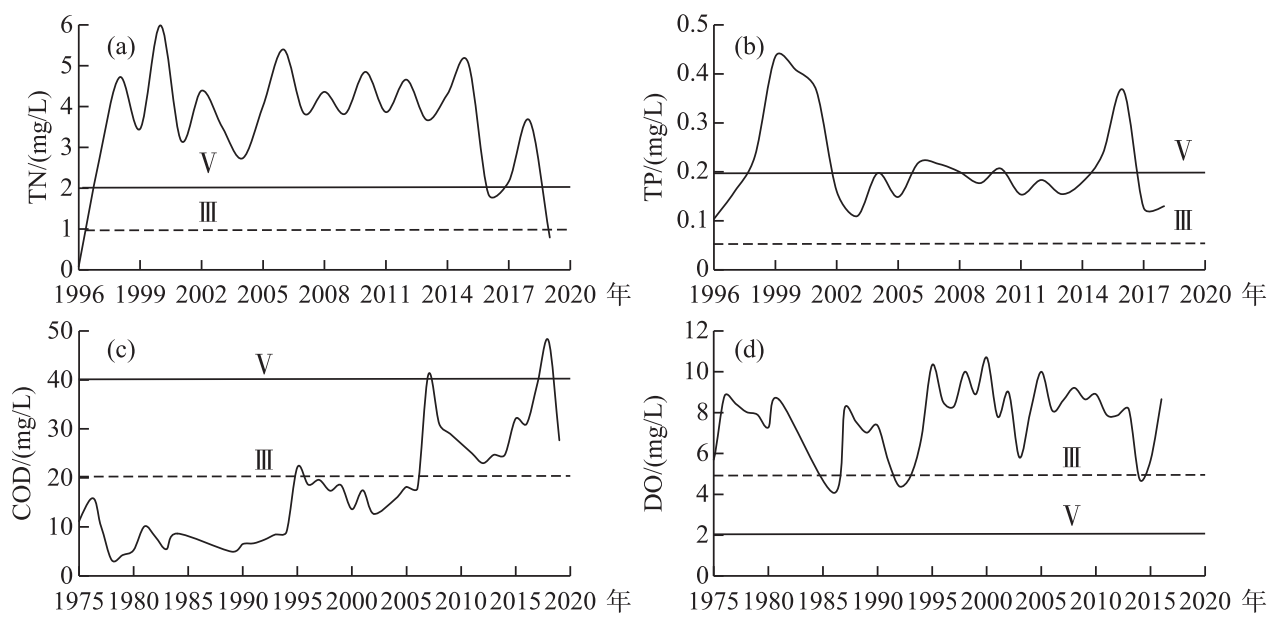

图 7 白洋淀淀区水体主要水质因子逐年浓度: ( a ) 总氮; (b) 总磷; ( c) 化学需氧量; (d) 溶解氧 ${ }^{[20,31-32]}$

Fig.7 Annual concentration level of main water quality factors in the water of Lake Baiyangdian:

(a) total nitrogen; (b) total phosphorus; (c) chemical oxygen demand; (d) dissolved oxygen ${ }^{[20,31-32]}$

\section{2 沉积物}

白洋淀位于“九河下梢”, 承接着上游的径流, 同时 也携带了大量的泥沙、营养物质和污染物质, 这些物质 随径流进人淀区后, 由于水流速度减缓, 悬浮物进一步 沉降, 大量的泥沙、营养物质和污染物沉积在淀区.

根据白洋淀上游河流 1951-1989 年间的实测输 沙量, 白洋淀上游河流多年平均输沙总量为 5871.02 万 $\mathrm{m}^{3}$, 多年平均输沙量为 173.1 万 $\mathrm{m}^{3}$, 多年平均出口输沙 量为 1.47 万 $\mathrm{m}^{3[35]}$, 大量泥沙在此淤积, 河床抬升. 进 人淀区的泥沙从河流人口附近呈扇形向中心区域逐渐 推进. 北部的藻窄淀泥沙淤积最为严重, 受泥沙淤积以 及水量减少的影响, 其平均水深不超过 $1 \mathrm{~m}$. 上游水库 的兴建大大缓解了人淀的泥沙量, 据估计, 上游水库拦 沙量约为 2 亿 $\mathrm{m}^{3}$. 图 9 为淀区不同采样点底泥的粒径 组成, 可以看出不同点的颗粒物粒径组成差异不大, 主 要为粉粒和黏粒.

结合 Guo 等于 2011 年对白洋淀泥柱同位素定年 以及相关元素分析结果 ${ }^{[13]}$ 和课题组近年对白洋淀底 泥采样的分析结果, 得出了白洋淀近 160 年来 TOC、 $\mathrm{TN} 、 \mathrm{As} 、 \mathrm{Cd} 、 \mathrm{~Pb}$ 和 $\mathrm{Hg}$ 的演变结果 (图 10). 总体来看, 除 了 As, 底泥中其他物质含量均逐步上升, 尤其在 1990s 以后都呈现出较快的增长趋势, 这也体现出底泥作为 污染物质的汇的特征.

保定市的发电厂、造纸工业和有色金属制造厂等 排出的工业废水经府河排人白洋淀, 是白洋淀沉积物 重金属污染的主要来源之一 ${ }^{[36]}$; 同时淀内的旅游业、

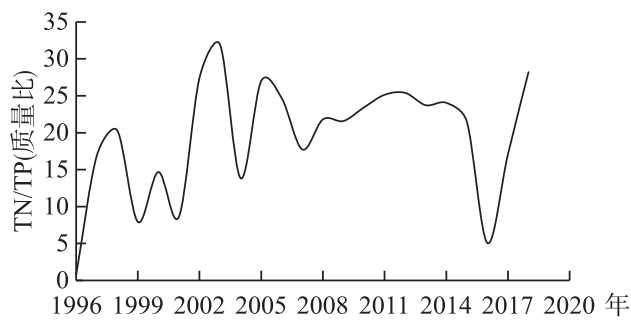

图 8 1996-2018 年白洋淀 水体氮磷组成比率

Fig. 8 TN/TP of water body in Lake Baiyangdian from 1996 to 2018

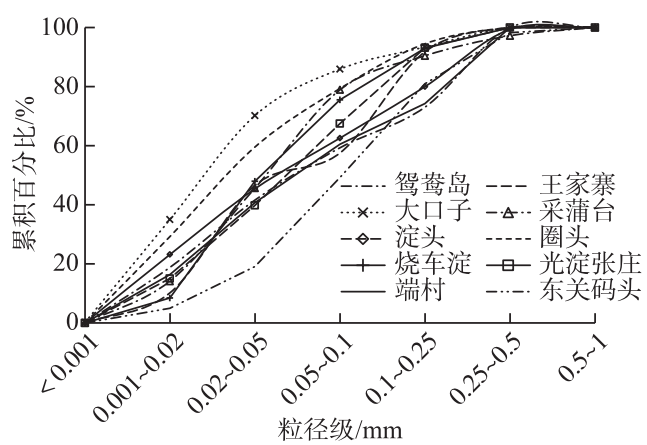

图 9 白洋淀不同采样点沉积物粒径组成

Fig.9 Composition of sediment particle size at different sampling sites of Lake Baiyangdian 
游船用柴油、养殖业等也在一定程度上带来重金属污染. 基于此,国内外学者对白洋淀沉积物重金属污染特 征与风险评价开展了大量研究. 对白洋淀表层沉积物采样, 结果显示: 白洋淀底泥重金属 $\mathrm{As} 、 \mathrm{Cd} 、 \mathrm{Cr} 、 \mathrm{Cu} 、 \mathrm{Mn}$ 、 $\mathrm{Ni} 、 \mathrm{~Pb}$ 和 $\mathrm{Zn}$ 的干重含量分别为 $5.40 \sim 12.09 、 0.17 \sim 0.55 、 45.50 \sim 68.04 、 20.16 \sim 63.35 、 482.27 \sim 739.72 、 21.33 \sim$ $54.99 、 15.71 \sim 54.99 、 16.16 \sim 23.10$ 和 $63.55 \sim 105.66 \mathrm{mg} / \mathrm{kg}^{[12]}$. 淀内整体上呈现出营养元素 “西北高东南低”、 重金属“中部高南北低” 的空间变化特征, 高潜在风险区的空间分布主要集中在湖东西之间的河流廊道上, 中等潜在危险区主要集中在附近湖边的城镇和村庄 ${ }^{[37]}$. 淀内表层沉积物中污染最为严重的元素为 $\mathrm{Cd}$, 其他 元素 $\mathrm{Cu} 、 \mathrm{Zn} 、 \mathrm{Cr} 、 \mathrm{Ni} 、 \mathrm{Co}$ 及 $\mathrm{Sn}$ 为中度污染; $\mathrm{Cu} 、 \mathrm{~Pb} 、 \mathrm{Zn} 、 \mathrm{Cr}$ 及 $\mathrm{Ni}$ 具有轻微潜在生态风险, 而元素 $\mathrm{Cd}$ 具有强潜在 生态风险 ${ }^{[38]}$. 未来, 处理表层沉积物中 $\mathrm{Cd}$ 污染将成为白洋淀生态修复的重要课题.
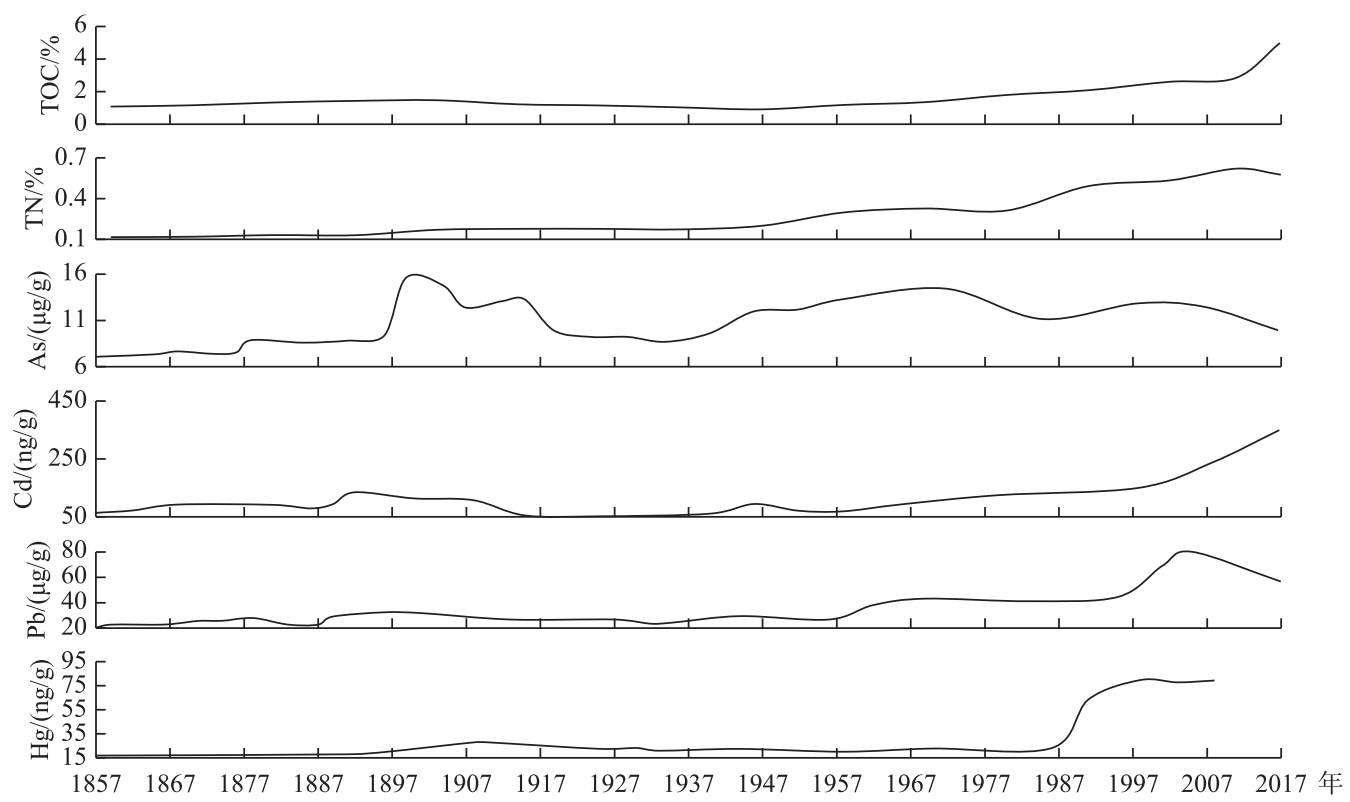

图 10 白洋淀不同沉积层深度对应年代的总有机碳、总氮和重金属干重含量 ${ }^{[13]}$

Fig.10 Total organic carbon, total nitrogen and heavy metals contents at different sedimentary depths corresponding to different ages in Lake Baiyangdian ${ }^{[13]}$

\section{4 水生态}

\section{1 水生维管束植物}

大型水生维管束植物是水域生态系统的初级生产者, 为其他生物提供食物和栖息场所. 白洋淀作为典 型浅水草型湖泊,广阔的水域面积和适宜的气候, 为水生动植物提供了良好的生存和繁殖环境. 历史上白洋 淀是一个水草丰美的鱼鸟之乡,水生维管束植物的覆盖度达 30\% 40\% . 水生维管束植物包括挺水植物、沉 水植物、漂浮植物和浮叶植物 4 大类, 其中挺水植物和沉水植物是白洋淀的主要优势类群. 挺水植物的优势 种主要有芦苇 (Phragmites australis)、莲 (Nelumbo sp.) 和狭叶香蒲 (Typha angustifolia L.) ; 沉水植物的优势物 种包括金鱼藻 (Ceratophyllum demersum L.)、菹草 (Potamogeton crispus L.) 、龙须眼子菜 (Potamogeton pectinatus $)$ 等, 且随季节变化, 根据 2015 年的调查结果显示, 沉水植物优势物种春季为菹草, 夏季为金鱼藻, 秋季为龙须眼子菜和金鱼藻.

据文献记载, 1958 和 1975 年白洋淀有水生维管束植物 34 种 ${ }^{[39-40]}$, 远小于 1979 年记载的 66 种, 可能是 由于当时的采样频率和强度所致. 近 40 年来白洋淀水生维管束植物种数和组成变化如图 11 所示 ${ }^{[41-46]}$. 总 体来看, 1979-2018 年白洋淀水生维管束植物种数逐步降低, 其中减少最为明显的是 1979-1990 年 ( I ) 和 2007-2011 年 (II) 两个时期. 第 I 时期挺水、浮叶和沉水植被种类分别由 28 、13 和 20 种减少至 18 、8 和 15 
种,其减少的原因可能主要是 1980s 持续干淀导致对水 位和地形敏感的物种消失. $1990-2007$ 年,水生维管束 植物种数较为稳定. 然而在 2007-2011 年种类数又大幅 下降, 此次主要减少的物种是挺水植物, 由原来的 16 种 减少到 7 种,其原因可能是补水工程的实施保证了水位 维持在一定的水平, 这促使需要一定水深条件但是对水 位变幅不敏感的物种则能维持较好的生长; 但短时间高 流量的补水措施虽然抬升了水位, 而反季相的补水扰乱 了白洋淀水位的自然波动节律, 与植物的生长周期所需 水位不匹配, 导致一些对淹水深度和周期敏感的物种 死亡.

\section{2 浮游生物}

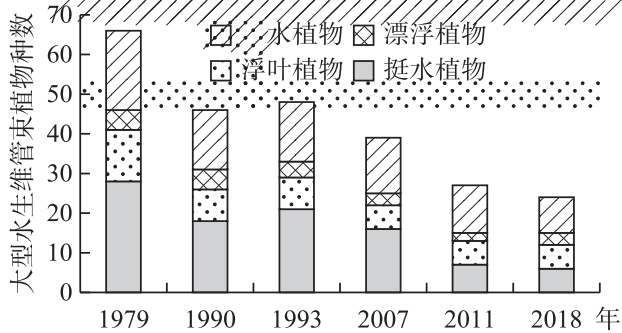

图 11 不同年份白洋淀大型水生维 管束植物种数及组成 ${ }^{[39-46]}$

Fig.11 Species and composition of large aquatic plants in Lake Baiyangdian in different years ${ }^{[39-46]}$

浮游植物位于食物链的底端, 是水生态系统的主要

初级生产者, 对水质的变化非常敏感. 大量研究通过藻类的密度、群落结构和功能组成来反映水体的营养状 态. 总体来看, 1958 年至今白洋淀浮游植物的物种数呈下降趋势. 图 12a 为白洋淀浮游植物物种数及物种组 成的演变过程 ${ }^{[47-57]} .1958$ 年 (未受污染时期) 白洋淀有浮游植物 129 属, 1975 年降到 92 属, 无隐藻记录 ${ }^{[47]}$. 导致该时期物种数下降的原因可能为 1960s 中期伊始的兴修水利工程, 加之极端干旱导致的 5、6 次干淀, 以 及人类活动增强导致的水质下降等. 直至 1982-1983 年 (干淀前) 仅有浮游植物 63 属, 且黄藻消失并出现 隐藻. 1984 年彻底干淀, 水生生物几近绝迹. 1988 年由于连降暴雨及人淀河流上游山洪汇集, 白洋淀重新蓄 水,浮游植物迅速恢复,到 1991 年已鉴定到 135 属 263 种, 比历史上最高水平的 1958 年多 6 属, 细胞密度年 均值达到 $425.1 \times 10^{4} \mathrm{cells} / \mathrm{L}$, 是干淀前的 3 倍以上, 种类组成和数量均恢复到干淀前的水平 ${ }^{[42]}$. 从 $1990 \mathrm{~s}$ 开 始, 浮游植物物种数从 1991 年的 263 种下降到 1996 年的 170 种, 2013 年文献记载的浮游植物物种数量到达 谷底值 (69 种), 1990-2013 年白洋淀浮游植物物种数急剧降低且优势群落逐渐由硅藻门转变为蓝藻门和 绿藻门, 这是因为工农业的快速发展导致大量的污染物和营养物质滞留在水体和沉积物中, 使白洋淀水体 富营养化加剧. 2018 年采集到浮游植物共 102 种, 其中蓝、绿藻门比例下降, 硅藻门比例上升, 说明雄安新区 规划建设后, 跨流域补水与水污染治理等多重生态修复工程初见成效. 浮游动物是水生态系统中的初级消 费者与被捕食者, 是维持食物网丰富和稳定的重要组成部分, 其物种丰富度、群落结构和生物多样性等特征 是营养状况的良好指标, 且对湖泊污染和富营养化程度关系密切. 1958-2018 年白洋淀浮游动物物种数同 样呈现逐步下降的趋势 (图 12b $)^{[47-57]}$. 从 1958-1975 年, 浮游动物物种数大幅减少. 1975-1993 年白洋淀 水产养殖业发达, 从外地调人大量渔业种质资源, 随之引人部分浮游甲壳动物, 浮游动物物种数下降减 缓 ${ }^{[58]}$. 从 1993 年开始, 从府河输入的生活污水和工业废水持续增加, 进人淀区的污染物于部分区域超过了 白洋淀的自净能力 ${ }^{[59-60]}$, 导致浮游动物在此期间急剧减少, 2015 年浮游动物物种数仅为 25 种, 优势种如微 型裸腹溞 (Moina micrura Kurz)、角突臂尾轮虫 (Brachionus angularis)、针簇多肢轮虫 (Polyarthra trigla) 等多
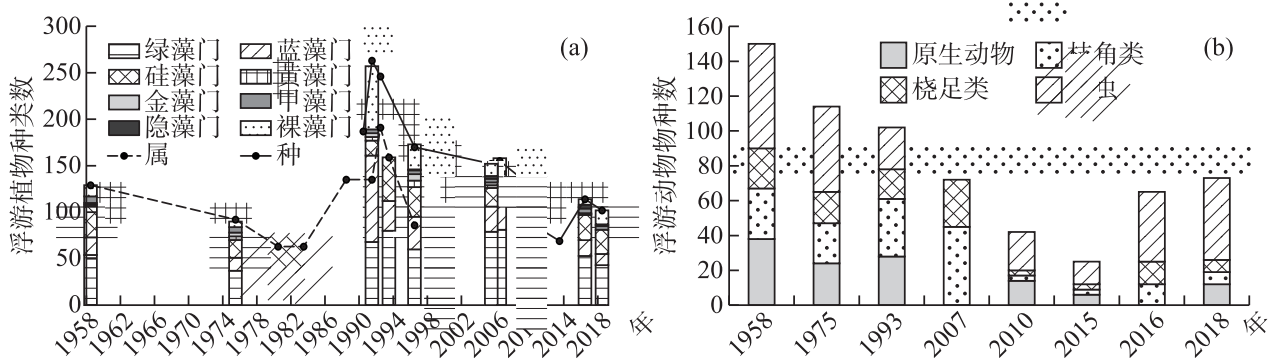

图 12 白洋淀浮游植物 ( a ) 和浮游动物 $(\mathrm{b})$ 物种数的历史演变趋势 ${ }^{[47-57]}$

Fig.12 Historical evolution trend of species richness of phytoplankton (a) and zooplankton (b) in Lake Baiyangdian ${ }^{[47-57]}$ 
为耐污种. 近 3 年, 浮游动物物种数有所回升, 且耐污种的比例有所下降,洁净水体中广为分布的物种如尖 额溞(Alona sp.)、象鼻溞(Bosmina sp.) 等物种重新被发现, 说明在国家和地方政府对环境的努力治理下,淀 区水质有所改善.

\section{3 底栖动物}

大型底栖无脊椎动物 ( 以下简称“底栖动物”) 是湖泊生态系统中的重要组成成分, 可以加快有机碎屑 分解、促进水一泥界面的物质交换, 在物质循环和能量流动中扮演着重要角色, 是食物网的重要一环. 白洋淀 属于泥质沉积环境, 水生植物腐烂后, 大量的有机质沉积水底, 有力地促进底栖动物繁育、生长. 底栖动物总 体上经历了先增加后减少的趋势, 优势种主要为软体和节肢类. 1958 年记录底栖动物 28 种, 1975 年 38 种, 增加的种类主要是软体动物, 从 11 种增加到 17 种; 到 1980 年一直维持在 30 多种. 至 1990s 锐减至 22 种,

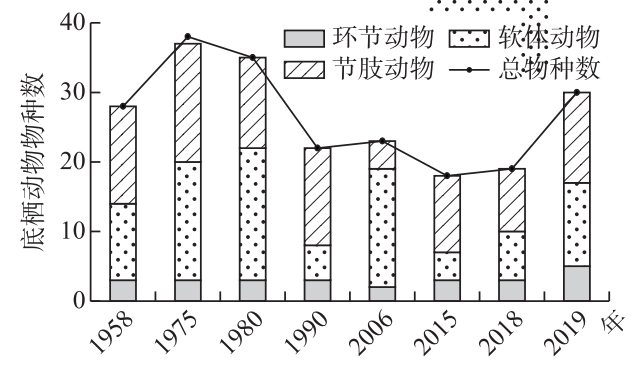

图 13 白洋淀底栖动物物种数变化 ${ }^{[39,47,61-63]}$

Fig.13 Variation of benthic animal species richness in Lake Baiyangdian ${ }^{[39,47,61-63]}$

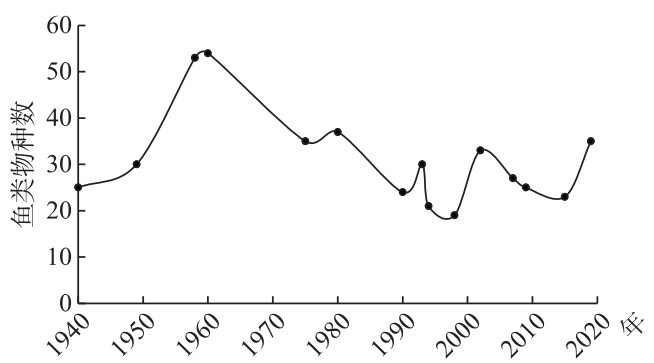

图 14 白洋淀鱼类物种数变化 ${ }^{[17,47,66-72]}$

Fig.14 Variation of fishes species richness in Lake Baiyangdian ${ }^{[17,47,66-72]}$
优势类群从软体动物变为节肢动物, 双壳类物种数量明 显减少, 而寡毛类物种数量增加 (图 13 $)^{[39,47,61-63]} .1958$ 年的物种主要包括软体动物 11 种、贻贝 7 种、虾类 4 种 和许多清洁种如蜻蜓和蜉蝣目幼虫等. 1990s, 螺蚌、蟹 等物种消失, 其他软体动物减少到 5 种, 摇蚊 (Chironomidae）、寡毛纲和其他耐染物种比例显著增加, 水质条 件恶化是造成耐污性低的生物从白洋淀生态系统中消 失或灭绝的重要原因 ${ }^{[62-63]}$, 之后白洋淀底栖动物种类稳 定在 $20 \sim 25$ 种. 近年来由于环境污染, 白洋淀底栖动物 群落结构较为单一, 以摇蚊、颤蚓等耐污物种为主, 多样 性相对较低 ${ }^{[64]}$. 2018、2019 年持续的大量补水, 白洋淀 水质向好, 底栖动物物种数也有所回升. 近期, 为控制和 修复白洋淀底泥污染实施的河道清淤工程也会对底栖 动物造成一定的影响 ${ }^{[65]}$.

\section{4 鱼类}

1950s 之前, 白洋淀水域辽阔、水质良好且水产资 源丰富, 享有 “华北之肾” 的美誉. 历史记载的鱼类物种 数相对较少可能和当时处于战争年代以及调查的力度 不够有关 (图 14 $)^{[17,47,66-72]} .1958$ 年对鱼类进行调查, 共 鉴定到 11 目 17 科 54 种, 鱼的种类和数量都很丰富, 经 济鱼类以鲤科 (Cyprinidae) 为主, 尚存在洄游性的鱼 类, 如鲻科 (Mugilidae)、鳗鲡科 (Anguillidae) 等 ${ }^{[66]}$. 1958 年人淀河系上游开始修建水利工程, 人淀水量大 幅度减少, 1976 年调查发现 5 目 11 科 33 属 35 种, 缺 少鲻科、鳗鲡科等溯河性鱼类, 种群组成仍以鲤科占优势, 共计 21 种, 占总数的 $60.0 \%{ }^{[47]} .1980$ 年调查到 40 种, 隶属 8 目 14 科 37 属, 鲤科 25 种, 占总数的 62.5\%. 彼时, 白洋淀的优势物种有白鲦鱼 (Hemiculter leucisculus), 主要物种仍为鲤科鱼类 ${ }^{[67]} .1983$ 年后, 白洋淀连续出现周期性干淀, 淀内鱼类资源大大减少, 1989 1991 年的两次调查分别仅得到 24 种鱼类, 为历次调查最低值 ${ }^{[68-69]}$. 经济价值较大的有鳗鲡科鱼类、梭鱼 (Sphyraenus)、鳡鱼 (Elopichthys bambusa)、赤眼鳟( Squaliobarbus curriculus) 等, 自 1980s 干淀之后再未发 现 $^{[70]} .1997$ 年后, 随着调水补淀工程以及污染治理措施的实施, 淀内鱼种类稳定在 25 种左右, 其中 2002 年 调查的鱼类 33 种, 含人工养殖的经济种类 10 种 ${ }^{[71]}$, 隶属 7 目 12 科 30 属. 主要的经济鱼类中, 有 10 种目前 已成为人工养殖的种类, 其中鲤的人工养殖品种还有红鲤、镜鲤等. 在自然组分中, 鲤科种类占 $51.5 \%$; 渔获 物中鲤、鲫(Carassius auratus auratus)、白鲦(Hemiculter leucisculus)、麦穗鱼 (Pseudorasbora parva) 居多, 表现 出了江河平原动物区系、河海亚区鱼类组成的特点. 2003 年开始, 白洋淀开始对经济鱼类进行增殖放流, 增 加了经济鱼类的产量, 但对物种的增加没有贡献 ${ }^{[71]}$. 2010、2011 年共调查到白洋淀水域鱼类 33 种, 隶属于 7 
目 12 科 30 属,鲫耐污染、耐低氧,已成为优势种群,洄游性鱼几乎全部消失,一些大型的经济鱼类也相继消 失 ${ }^{[17,72]} .2015$ 年共调查到 6 目 9 科 23 种鱼类,优势种仍然以网箱养殖的经济鱼类鲤科为主 $(35 \%)$, 此外还 发现近年来濒临绝迹的青鱗 (Oryzias latipes), 表明白洋淀的生态环境在日趋改善.

\section{5 其他生物}

白洋淀湿地由于水浅草多、光照充足、气候适宜, 野生动物种类繁多, 生物资源丰富, 被誉为 “生物资源 和野生动物种群的基因库”. 据统计, 干淀以前, 白洋淀内有鸟类 192 种, 隶属于 16 目 46 科 102 属, 有国家级 保护鸟类 187 种,其中国家 I 级保护鸟类 3 种, 国家 II 级保护鸟类 26 种. 哺乳动物 14 种,隶属于 5 目 8 科 12 属, 有国家级保护动物 5 种. 两栖动物 3 种, 隶属于 1 目 2 科 2 属, 均为我国保护的有益或有重要经济科学研 究价值的陆生野生动物. 爬行动物共有 11 种, 隶属于 2 目 4 科 7 属. 1970s 以后, 受人淀水量减少、上游水库 控制下水文情势变异、水污染问题严重和资源过度开发等影响, 野生动物的生存环境恶化, 过去经常出没的 一些大型猛禽如金雕 (Aquila chrysaetos)、赤狐 (Vulpes vulpes) 等已难受踪影, 珍稀鸟类逐渐减少. 1983 年发生 持续干淀后, 珍贵鸟类濒于绝迹. 1988 年恢复蓄水, 水禽种数有所回升, 但鸿雁 (Anser cygnoides)、斑嘴鸭 (Anas zonorhyncha)、绿头鸭 (Anas platyrhynchos) 等数量仍较少. 施行常态补水措施以来, 水面开阔、候鸟大量 增加,一些绝迹多年的水禽水鸟又回到白洋淀的芦苇丛中. 据安新县 2004 年观测数据, 白洋淀野生禽鸟、灰 鹤 (Grus grus)、豆雁(Anser fabalis) 数增加, 多年不见的白天鹅(Cygnus cygnus)、东方白鹤(Grus leugeranus) 再 度出现 ${ }^{[59]}$.

总体而言, 自 1960s 以来, 白洋淀的水生植被、浮游植物、浮游动物、大型底栖动物和鱼类的物种数均呈 现先增加后减少的趋势, 1960s - 1970s 是白洋淀生物资源最为丰富的年代, 之后受干旱、水体污染的影响, 白洋淀的生物资源逐渐减少, 部分物种甚至在此区域绝迹. 尤其是 2017 年雄安新区设立以来, 白洋淀的水 环境污染和水生态恢复开始得到重视和治理, 水量和水质得到了大幅提升, 物种的多样性正在逐步恢复, 白 洋淀水生态系统得以恢复.

\section{5 结论}

本文结合历史资料、相关文献数据以及课题组长期的实测数据, 回顾并探究了白洋淀近 60 年来的生态 环境演变规律. 结果表明,白洋淀的多年降水量呈减少趋势, 受气候影响以及上游大坝拦截, 天然人淀水量 持续减少, 淀区水位下降甚至在 1980s 出现长时间干淀, 导致白洋淀的水生动植物, 如鱼类、水生维管束植 物、浮游植物、浮游动物以及大型底栖生物的物种数减少, 甚至导致部分物种灭绝; 同时耐污染、耐低氧种类 所占比例上升. 为恢复白洋淀水位与水生态, 流域内和跨流域生态补水为白洋淀带来了新鲜血液, 同时为湖 泊生态恢复提供了重要的先决条件. 在生态补水的影响下, 淀区水位日渐上升, 白洋淀整体水质由 $\mathrm{V} \sim$ 劣 $\mathrm{V}$ 类水逐渐好转为 $\mathrm{I} \sim \mathrm{V}$ 类水, 湖泊水体中营养物质(氮、磷) 浓度逐渐降低,生物资源也逐渐恢复.

然而, 作为雄安新区的关键生态屏障, 对白洋淀水环境和水生态的治理要求提出了新高度. 白洋淀流域 内农业面源污染的控制和周边生活垃圾及污水的控制治理已取得初步成效,水质趋好, 基本能达到 IV 类水 标准. 然而离规划的目标 III 类水标准还有一定距离. 从劣 $\mathrm{V}$ 类、 $\mathrm{V}$ 类提升到 $\mathrm{IV}$ 类水的过程主要通过控源截污 实现,进一步从 $\mathrm{I}$ 类水提升到 III 类水则是更为艰巨的过程, 在控源截污的基础上, 还需要通过多水源大量补 水, 降低淀区水力滞留时间, 提高淀区水体的环境容量, 实现淀区的进一步净化. 同时生态补水的节律与水 生生物生命节律匹配的问题还值得进一步关注. 作为沉积作用强的浅水湖泊, 底泥在长期污染过程中充当 着污染物 “汇” 的角色, 在淀区水体质量好转后其转换成 “源” 的角色, 如何采取有效的底泥污染治理措施, 也是目前亟需解决的问题. 水质问题逐步改善, 水生生物群落亦将逐步恢复, 达到新的平衡, 下一步需要明 晰健康的生态系统应该有怎样的物种组成和食物链构成. 在雄安新区建设规划的推动下,希望白洋淀这颗 “明珠” 早日重拾往日光彩, 展现荷塘苇海自然景色, 实现建成蓝绿交织、水城和谐共融的生态新城.

\section{6 附录}

附表 I 和附图 I 见电子版( DOI: 10.18307/2020.0500). 


\section{7 参考文献}

[ 1 ] Dodds WK, Perkin JS, Gerken JE. Human impact on freshwater ecosystem services: A global perspective. Environmental Science \& Technology, 2013, 47(16) : 9061-9068. DOI: 10.1021/es4021052.

[ 2 ] Copeland HE, Tessman SA, Girvetz EH et al. A geospatial assessment on the distribution, condition, and vulnerability of Wyoming's wetlands. Ecological Indicators, 2010, 10(4) : 869-879. DOI: 10.1016/j.ecolind.2010.01.011.

[ 3 ] Zhang M, Gong ZN, Zhao WJ. Analysis of driving forces of Baiyangdian wetland evolution during 1984-2013. Chinese Journal of Ecology, 2016, 35(2) : 499-507. DOI: 10.13292/j.1000-4890.201602.017. [张敏, 宫兆宁, 赵文吉. 近 30 年来白洋淀湿地演变驱动因子分析. 生态学杂志, 2016, 35(2): 499-507.]

[ 4 ] Lienert J, Diemer M, Schmid B. Effects of habitat fragmentation on population structure and fitness components of the wetland specialist Swertia perennis L. (Gentianaceae). Basic and Applied Ecology, 2002, 3(2) : 101-114. DOI: 10.1078/ 1439-1791-00089.

[ 5 ] Xu HB, Qiao HJ, Lei YR. Analysis on the current situation and countermeasures of wetland protection in China. South China Agriculture, 2018, 12(19) : 19-20, 23. [徐慧博, 乔红娟, 雷茵茹. 中国湿地保护现状问题及对策分析. 南方 农业, 2018, 12(19) : 19-20, 23.]

[ 6 ] Gong YB. The spatial-temporal pattern evoluation of wetland landscape and its driving mechanism in Changsha [Dissertation]. Changsha: Central South University of Forestry and Technology, 2013. [恭映璧. 长沙城市湿地景观格局时空演 变与驱动机制研究 [学位论文]. 长沙: 中南林业科技大学, 2013.]

[ 7 ] Cao TG, Yi YJ, Liu HX et al. Integrated ecosystem services-based calculation of ecological water demand for a macrophyte-dominated shallow lake. Global Ecology and Conservation, 2020, 21: e00858.

[ 8 ] Tang CH, Yi YJ, Yang ZF et al. Effects of ecological flow release patterns on water quality and ecological restoration of Baiyangdian Lake. Journal of Cleaner Production, 2018, 174: 577-590. DOI: 10.1016/j.jclepro.2017.10.338.

[ 9 ] Huo XG, Zhang XD, Wang M et al. State affairs-A documentary on the planning and construction of Xiong'an new area in Hebei province, which was decided by the CPC central committee with comrade Xi Jinping as the core. Policy Research \& Exploration, 2017, (5): 62-67. [霍小光, 张旭东, 王敏等. 千年大计 国家大事一以以近平同志为核心的党中央 决策河北雄安新区规划建设纪实. 决策探索: 上半月, 2017, (5):62-67.]

[10] Hebei Provincial Party Committee and Government. Baiyangdian ecological environment management and protection plan （2018-2035)，2019. [ 河北省委、省政府. 白洋淀生态环境治理和保护规划 (2018－2035 年)，2019.]

[11] Zhang XX, Yi YJ, Yang ZF. Nitrogen and phosphorus retention budgets of a semiarid plain basin under different human activity intensity. Science of the Total Environment, 2020, 703: 134813. DOI: 10.1016/j.scitotenv.2019.134813.

[12] Zerizghi T, Yang YF, Wang WJ et al. Ecological risk assessment of heavy metal concentrations in sediment and fish of a shallow lake: A case study of Baiyangdian Lake, North China. Environmental Monitoring and Assessment, 2020, 192(2) : 154. DOI: $10.1007 / \mathrm{s} 10661-020-8078-8$.

[13] Guo W, Huo SL, Ding WJ. Historical record of human impact in a lake of northern China: Magnetic susceptibility, nutrients, heavy metals and OCPs. Ecological Indicators, 2015, 57: 74-81. DOI: 10.1016/j.ecolind.2015.04.019.

[14] Yang YF, Yi YJ, Wang WJ et al. Generalized additive models for biomass simulation of submerged macrophytes in a shallow lake. Science of the Total Environment, 2020, 711: 135108. DOI: 10.1016/j.scitotenv.2019.135108.

[15] Tang CH, Yi YJ, Yang ZF et al. Planktonic indicators of trophic states for a shallow lake (Baiyangdian Lake, China). Limnologica, 2019, 78: 125712. DOI: 10.1016/j.limno.2019.125712.

[16] Yi YJ, Yang YF, Zhang SH et al. Habitat simulation of benthic macroinvertebrates in a shallow lake. Water Resources and Hydropower Engineering, 2019, 50(5): 90-96. [易雨君, 杨雨风, 张尚弘等. 浅水湖泊底栖动物栖息地模拟. 水利 水电技术, $2019, \mathbf{5 0}(5): 90-96$. ]

[17] Chen L, Xie GD, Lu CX et al. Impacts of hydropower projects on fishes: A case study of Baiyangdian Lake over the recent 50 years. Resources Science, 2011, 33(8): 1475-1480. [陈龙, 谢高地, 鲁春霞等. 水利工程对鱼类生存环境的影 响一一近 50 年白洋淀鱼类变化为例. 资源科学, 2011, 33(8): 1475-1480.]

[18] Wang WJ, Yi YJ, Yang YF et al. Impact of anthropogenic activities on the sediment microbial communities of Baiyangdian shallow lake. International Journal of Sediment Research, 2020, 35(2) : 180-192. DOI: 10.1016/j.ijsrc.2019.10.006. 
[19] Wang J, Xu ZX. Long-term trend and the sustainability of air temperature and precipitation in the Baiyangdian basin. Resources Science, 2009, 31(9)：1498-1505. [王洁, 徐宗学. 白洋淀流域气温与降水量长期变化趋势及其持续性分 析. 资源科学, 2009, 31(9) : 1498-1505.]

[20] Environmental Protection Agency in Baoding. Baoding environmental quality report ( $2006-2010)$. Baoding: Environmental Protection Agency in Baoding, 2011. [保定市环境保护局. 保定市环境质量报告书 (2006- 2010 年 度). 保定: 保定市环境保护局, 2011.]

[21] Hebei Local Committee ed. Hebei Chi, the System of the People's Congress. Hebei: Hebei Peoples Publishing House, 1993. [河北省地方纂委员会. 河北省志·人民代表大会制志. 河北: 河北人民出版社, 1993.]

[22] Walter H, Breckle SW eds. Ecological zonation of the geobiosphere. Ecological systems of the geobiosphere. Berlin, Heidelberg: Springer, 1985: 15-40. DOI: 10.1007/978-3-662-02437-9_3.

[23] Huang JP, Cheng DS, Deng JQ et al. Climate analysis of Dongjiang river basin. Pearl River, 2006, 27(5) : 48-52. [ 黄金 平, 程东升, 邓家泉等. 东江流域气候分析. 人民珠江, 2006, 27(5): 48-52.]

[24] Li X, Shou SW, Bai YH et al. Characteristics of climate change from 1960 to 2013 in Baiyangdian wetland. Journal of Meteorology and Environment, 2016, 32(1) : 75-83. [李祥, 寿绍文, 白艳辉等. 1960-2013 年白洋淀湿地气候变化特 征分析. 气象与环境学报, 2016, 32(1): 75-83.]

[25] Ren W, Xu GB. Analysis on the natural flow into Baiyangdian Lake based on the GA-grey wave forecasting model. Southto-North Water Transfers and Water Science \& Technology, 2017, 15(5) : 9-14, 49. [任旺, 徐国宾. 基于 GA-灰色波形 预测模型的白洋淀天然人淀水量. 南水北调与水利科技, 2017, 15(5): 9-14, 49.]

[26] Yin JM, Cheng WQ, Yan L et al. Change of water resources in the Baiyangdian Wetland. Water Resources Protection, 2009, 25(1) : 52-54, 58. [尹健梅, 程伍群, 严否等. 白洋淀湿地水文水资源变化趋势分析. 水资源保护, 2009, $25(1): 52-54,58$.

[27] Yang W, Yang ZF. Effects of long-term environmental flow releases on the restoration and preservation of Baiyangdian Lake, a regulated Chinese freshwater lake. Hydrobiologia, 2014, 730(1) : 79-91. DOI: 10.1007/s10750-014-1823-7.

[28] Yang W, Sun L, Wang X et al. Changes in ecosystem services in Baiyangdian Lake driven by environmental flow releases. Journal of Agro-Environment Science [2020-04-25]. http://kns. cnki. net/kcms/detail/12.1347. S. 20200421.1318.002. html. [杨薇, 孙立釒金, 王烜等. 生态补水驱动下白洋淀生态系统服务演变趋. 农业环境科学学报 [2020-04-25].]

[29] National Bureau of Statistics of the People's Republic of China ed. China statistics yearbook on environment. Beijing: China Statistics Press, 2010. [ 国家统计局. 中国环境统计年鉴. 北京: 中国统计出版社, 2010.]

[30 ] Ministry of Ecology and Environment, PRC. Surface water and ambient air quality in China in 2019. http://www.mee.gov. $\mathrm{cn} / \mathrm{hjzl} / \mathrm{shj} / \mathrm{qgdbszlzk} . h t m l$. [中华人民共和国生态环境部. 2019 年全国地表水、环境空气质量状况. ]

[31] China Environmental Yearbook Editorial Board ed. China environmental yearbook. Beijing: China environmental Science Press, 1992. [中国环境年鉴编辑委员会. 中国环境年鉴. 北京: 中国环境科学出版社, 1992.]

[32] Anxin County Local Chronicles Compilation Committee ed. Anxin county Chronicles. Beijing: Xinhua Publishing House, 2000: 152. [安新县地方志编纂委员会. 安新县志. 北京: 新华出版社, 2000: 152.]

[33] Guildford SJ, Hecky RE. Total nitrogen, total phosphorus, and nutrient limitation in lakes and oceans: Is there a common relationship? Limnology and Oceanography, 2000, 45(6) : 1213-1223. DOI: 10.4319/lo.2000.45.6.1213.

[34] Redfield AC. The influence of organisms on the composition of seawater. The Sea, 1963, 2 : 26-77.

[35] Li ZQ, Liu JZ, Wang WX. The analysis of Baiyangdian silt sedimentation. Hebei Water Resources and Hydropower Engineering, 2002, (2) : 31-32. [李振卿, 刘建芝, 王卫喜. 白洋淀泥沙淤积成因分析. 河北水利水电技术, 2002, (2) : 31-32.]

[36] Gao L, Han LF, Peng WQ et al. Identification of anthropogenic inputs of trace metals in lake sediments using geochemical baseline and $\mathrm{Pb}$ isotopic composition. Ecotoxicology and Environmental Safety, 2018, 164: 226-233. DOI: 10.1016/j.ecoenv.2018.08.014.

[37] Ji ZH, Zhang H, Zhang Y et al. Distribution, ecological risk and source identification of heavy metals in sediments from the Baiyangdian Lake, Northern China. Chemosphere, 2019, 237: 124425. DOI: 10.1016/j.chemosphere.2019.124425.

[38 ] Wang JZ, Liu Z, Wei H et al. Spatial characteristics, risk assessment, and source analysis of elements in surface sediments from the Baiyangdian Lake. Environmental Science, 2020, 41(1) : 224-231. DOI: 10.13227/j. hjkx. 201907005. [汪敬忠, 刘卓, 魏浩等. 白洋淀表层沉积物元素的空间特征、风险评价及来源分析. 环境科学, 2020, 41(1): 
224-231. ]

[39] Wen LQ. Changes and influencing factors of Baiyangdian water ecological environment. Chinese Journal of Environmental Science, 1995, 16(S1) : 50-52. DOI: 10.13227/j.hjkx.1995.s1.020. [ 文丽青. 白洋淀水生态环境的变迁及影响因素. 环境科学, $1995,16(\mathrm{~S} 1): 50-52$.]

[40] Zhao F. Investigation of large aquatic plant resources in Baiyangdian Lake and its influence on eutrophication. Environmental Science, 1995, (S1) : 21-23. [赵芳. 白洋淀大型水生植物资源调查及对富营养化的影响. 环境科学, 1995, (S1) : 21-23.]

[41] Chen Y. Preliminary analysis of aquatic flora in Baiyangdian Lake. Acta Phytotaxonomica Sinica, 1987, 25(2) : 106-113. [ 陈耀东. 白洋淀水生植物区系初步分析. 植物分类学报, 1987, 25(2)：106-113.]

[42] Zhang YK, Tian YM, Zhang XS. Studies on phytoplankton in Lake Baiyangdian. Acta Hydrobiologica Sinica, 1995,19 (4) : 317-326. [张义科, 田玉梅, 张雪松. 白洋淀浮游植物现状. 水生生物学报, 1995, 19(4) : 317-326.]

[43] Tuan YM, Zhang YK, Zhang XS. Aquatic vegetation in Lake Baiyangdian. Journal of Hebei University: Natural Science Edition, 1995, 15(4) : 59-66. [田玉梅, 张义科. 白洋淀水生植被. 河北大学学报: 自然科学版, 1995, 15(4): 59-66. ]

[44] Cui BS, Han Z eds. Driving mechanisms and regulating measures for Terriestrialization: A case of Lake Baiyangdian. Beijing: Science Press, 2017. [崔保山, 韩祯. 白洋淀沼泽化驱动机制与调控模式. 北京: 科学出版社, 2017.]

[45] Zhang L. Study on the relationship between the distribution of aquatic plant community and the environment factors in Baiyangdian Lake [Dissertation]. Baoding: Hebei University, 2019. [张蕾. 白洋淀水生植物群落分布与水环境因子关系 研究 [ 学位论文]. 保定: 河北大学, 2019.]

[46] Li F, Xie YH, Yang G et al. Preliminary survey on aquatic vegetation in Baiyangdian Lake. Chinese Journal of Applied Ecology , 2008, 19(7) : 1597-1603. DOI: 10.13287/j.1001-9332.2008.0263. [李峰, 谢永宏, 杨刚等. 白洋淀水生植 被初步调查. 应用生态学报, 2008, 19(7): 1597-1603.

[47] Institute of Geography, Hebei Academy of Sciences. Baiyangdian water conservation research atlas. Beijing: Science Press, 1983. [河北省科学院地理研究所. 白洋淀水源保护研究图集. 北京: 科学出版社, 1983.]

[48] Liu CQ, Liu LS, Shen HT. Seasonal variations of phytoplankton community structure in relation to physico-chemical factors in Lake Baiyangdian, China. Procedia Environmental Sciences, 2010, 2: 1622-1631. DOI: 10. 1016/j. proenv. 2010. 10.173 .

[49] Xu MQ, Zhu J, Huang YY et al. The ecological degradation and restoration of Baiyangdian Lake, China. Journal of Freshwater Ecology, 1998, 13(4) : 433-446. DOI: 10.1080/02705060.1998.9663640.

[50] Feng JS. Phytoplankton and water quality evaluation in Baiyangdian Lake. Jiang Su Environmental Science and Technology, 1999, 12(2) : 27-29. [冯建社. 白洋淀浮游植物与水质评价. 江苏环境科技, 1999, 12(2) : 27-29.]

[51] Gao Y, Xu M eds. Study on the relationship between phytoplankton community structure and water nutrient level in Baiyangdian Lake. Beijing: Science Press, 1994: 154-164. [高玉荣, 许木启. 白洋淀浮游植物群落结构特征与水体营养 水平关系的研究. 北京: 科学出版社, 1994: 154-164.]

[52] Shen HT, Liu CQ. Canonical correspondence analysis of phytoplankton community and its environmental factors in the Lake Baiyangdian. J Lake Sci, 2008, 20 (6) : 773-779. DOI: 10.18307/2008.0616. [沈会涛, 刘存歧. 白洋淀浮游植 物群落及其与环境因子的典范对应分析. 湖泊科学, 2008, 20(6) : 773-779.]

[53] Wang Y, Liu LS, Shu JM et al. Community structure of phytoplankton and the water quality assessment in Lake Baiyangdian. J Lake Sci, 2011, 23(4) : 575-580. DOI: 10.18307/2011.0413. [王瑜, 刘录三, 舒俭民等. 白洋淀浮游植物群落 结构与水质评价. 湖泊科学, $2011,23(4): 575-580$.

[54] Zhu XQ, Gong R, Mu ZY et al eds. Environmental evolution and prediction of Baiyangdian. Xi'an: Xi'an map publishing house, 1993: 15-72. [ 朱宣清, 弓冉, 穆仲义等. 白洋淀环境演变及预测. 西安: 西安地图出版社, 1993: 15-72.]

[55] Xu MQ. The development of eutrophication in Baiyangdian Lake from the perspective of zooplankton species diversity// Biodiversity Committee of the Chinese Academy of Sciences, Department of Wildlife and Forest Plant Protection of the Ministry of Forestry, Youth Working Committee of the Botany Society of China eds. Progress in biodiversity research-Proceedings of the first national symposium on biodiversity conservation and sustainable use. Beijing: China Science Press, 1994: 421-436. [许木启. 从浮游动物种类多样性变化看白洋淀富营养化的发展//中国科学院生物多样性委员会, 林业 部野生动物和森林植物保护司, 中国植物学会青年工作委员会. 生物多样性研究进展一一首届全国生物多样性 
保护与持续利用研讨会论文集: 北京: 中国科学出版社, 1994: 421-436.]

[56] Yang Y. Study on ecological water demand based on the dynamics of food web structure and function in the Baiyangdian wetland [Dissertation]. Beijing: Beijing Normal University, 2011. [杨盈. 基于食物网营养动力学的白洋淀湿地生态 需水研究 [学位论文]. 北京: 北京师范大学, 2011.]

[57] Zhang YW, Liu CQ, Xing XG et al. Cladocera and copepods of Baiyangdian, Hebei. Sichuan Journal of Zoology, 2008, (5) : 730. [张跃伟, 刘存歧, 邢晓光等. 河北白洋淀的枝角类和桡足类. 四川动物, 2008，(5): 730.]

[58] Yi L, Liu CQ, Xing XG et al. The biodiversity of crustacean zooplankton in Lake Baiyangdian. Journal of Hydroecology, 2010，31(4) : 38-43. [易否, 刘存歧, 邢晓光等. 白洋淀浮游甲壳动物的生物多样性研究. 水生态学杂志, 2010, 31 (4) : 38-43.]

[59] Gao F. Variation and prediction of the ecological environment of Baiyangdian Wetland [Dissertation]. Baoding: Hebei Agricultural University, 2008. [高芬. 白洋淀生态环境演变及预测 [学位论文]. 保定: 河北农业大学, 2008. ]

[60] Xu MQ. Evaluation of self-purification efficiency of fuhestream-Baiyangdian lake through zooplankton. Acta Hydrobiologica Sinica, 1996, 20 (3) : 212-220. [许木启. 从浮游动物群落结构与功能的变化看府河一一白洋淀水体的自净效果. 水生生物学报, 1996, 20(3): 212-220.]

[61] Peng JD. The diversity of insects from Baiyangdian wetlands [Dissertation]. Baoding: Hebei University, 2015. [彭吉栋. 白洋淀湿地昆虫多样性研究 [学位论文]. 保定: 河北大学, 2015.]

[62] Baiyangdian Station, Institute of Zoology, Chinese Academy of Sciences ed. Preliminary investigation report on Baiyangdian biological resources and their comprehensive utilization. Beijing: Science Press, 1958. [中国科学院动物研究所白洋淀 工作站. 白洋淀生物资源及其综合利用初步调查报告. 北京: 科学出版社, 1958.]

[63] Zhang S, Tang YJ eds. Study on water pollution control in Baiyangdian area. Beijing: Science Press, 1995. [章申, 唐以 剑. 白洋淀区域水污染控制研究. 北京: 科学出版社, 1995.]

[64] Yang YF, Yi YJ, Zhou Y et al. Influence factors of benthic macroinvertebrate community in Baiyangdian Lake. Water Resources and Hydropower Engineering, 2019, 50(2) : 21-27. [杨雨风, 易雨君, 周扬等. 白洋淀底栖动物群落影响因 子研究. 水利水电技术, $2019, \mathbf{5 0}(2): 21-27$.]

[65] Wang DS, Men B, Zhang MY. Sediment water ecotone and sediment removal of shallow lake: A case study of Baiyangdian Lake in Xiong'an New Area. Acta Scientiae Circumstantiae, 2020, 40 (5) : 1550-1559. DOI: 10.13671/j. hjkxxb.2019. 0457. [王东升, 门涁, 张美一. 论浅水湖泊中的水固交错带与科学清淤规划一以雄安新区白洋淀为例. 环境科 学学报, 2020, 40(5): 1550-1559.]

[66] Zheng BS, Fan QD, Dai DY eds. Fishes of Baiyangdian Lake. Tianjin: Hebei People's Publishing House, 1960. [郑葆 珊，范勤德，戴定远. 白洋淀鱼类. 天津: 河北人民出版社, 1960.]

[67] Zhao CL, Xiao GH, Luo NT et al. Analysis on the composition of fishes in Baiyangdian Lake. Hebei Fisheries, 2007, (11) : 49-50. [ 赵春龙, 肖国华, 罗念涛等. 白洋淀鱼类组成现状分析. 河北渔业, 2007, (11) : 49-50.]

[68] Cao YP. Preliminary report on the status of fish resources in Baiyangdian Lake after refill. Freshwater Fisheries, 1991,21 (5) : 20-22. [ 曹玉萍. 白洋淀重新蓄水后鱼类资源状况初报. 淡水渔业, 1991, 21(5): 20-22.]

[69] Han XF, Wang SA, Cao YP et al. Ecological analysis of the composition of fishes in Baiyangdian Lake after refill. Hebei Fisheries, 1991, (6) : 8-11. [韩希福, 王所安, 曹玉萍等. 白洋淀重新蓄水后鱼类组成的生态学分析. 河北渔业, $1991,(6): 8-11$.

[70] Xia XL, Zhai LT. Several economic fishes extinct in the wild state of Baiyangdian Lake and their cause. Hebei Fisheries, 2014, (5) : 63-64. [夏雪岭, 翟雷田. 几种在白洋淀野生状态下绝迹的经济鱼类及原因. 河北渔业, 2014, (5): 63-64.]

[71] Cao YP, Wang W, Zhang YB. Present situation of fish stocks in Baiyangdian Lake. Chinese Journal of Zoology, 2003,38 (3) : 65-69. DOI: 10.13859/j.cjz.2003.03.029. [曹玉萍, 王伟, 张永兵. 白洋淀鱼类组成现状. 动物学杂志, 2003, 38(3): 65-69.]

[72] Xie S, Huang BS, Wang HW et al. Assessment of water quality in Baiyangdian Lake by zoobenthos biodiversity. Journal of Hydroecology , 2010, 31 (1) : 43-48. DOI : 10.15928/j.1674-3075.2010.01.006. [谢松, 黄宝生, 王宏伟等. 白洋淀底 栖动物多样性调查及水质评价. 水生态学杂志, 2010, 31(1) : 43-48.] 
附表 I 白洋淀 Web of Science 检索不同分类关键词

Attached table I Web of Science retrieval of Baiyangdian with different classification keywords

\begin{tabular}{|c|c|}
\hline 问题 & 关键词组 \\
\hline 水质 & $\begin{array}{l}\text { "Baiyangdian + water quality" “ Baiyangdian + COD” “ Baiyangdian + DO”、“ Baiyangdian + TN" } \\
\text { "Baiyangdian+TP” }\end{array}$ \\
\hline $\begin{array}{l}\text { 富营养化 } \\
\text { 重金属 }\end{array}$ & $\begin{array}{l}\text { “Baiyangdian+nutrient”、“Baiyangdian+eutrophication ”, Baiyagdian+TN”、“Baiyangdian+TP” } \\
\text { "Baiyangdian+heavy metal”、"Baiyangdian+Cd”、"Baiyangdian+Cu”, "Baiyangdian+Zn”、 } \\
\text { "Baiyangdian+Pb” }\end{array}$ \\
\hline 新兴污染物 & $\begin{array}{l}\text { "Baiyangdian+ PFCs" " Baiyangdian + EDCs" 、 Baiyangdian + PPCPs" 、 Baiyangdian + PAHs" } \\
\text { "Baiyangdian+OCPs" }\end{array}$ \\
\hline
\end{tabular}
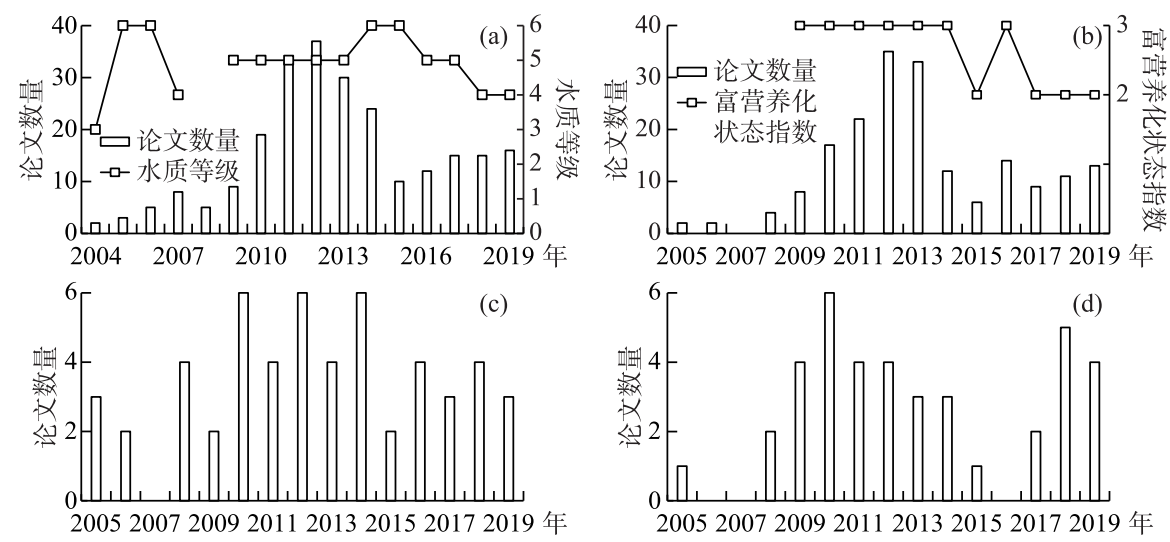

附图 I 白洋淀相关研究历年文献发表情况: (a) 水质; (b) 富营养化; (c) 重金属; (d) 新兴污染物 (水质等级 1 6 分别表示 $\mathrm{I} \sim$ 劣 $\mathrm{V}$ 类水体; 富营养化状态指数 3 为中度富营养, 2 为轻度富营养) ${ }^{[29-30]}$

Attached figure I Literature published about Lake Baiyangdian over the years: (a) water quality;

(b) eutrophication; (c) heavy metals; (d) emerging pollutants (the water quality grade 1 to

6 represent I -worse V water body, respectively; Eutrophication status index 3 represents moderate eutrophication, 2 represents mild eutrophication ${ }^{[29-30]}$ 